\title{
Production, Purification and Characterization of Mannanase Obtained from Pichia Kudriavzevii Strain AUMC 10190 Isolated from Citrus Wastes
}

Folake Titilayo Afolabi ( $\sim$ folakeojo1@yahoo.com )

University of Ibadan Faculty of Science https://orcid.org/0000-0001-8820-9711

YETUNDE ZAINAB JIMOH

Department of Microbiology, University of Ibadan, Nigeria

\section{Research}

Keywords: Gum Arabic, Mannanase, Pichia kudriavzevii (AUMC 101190), Yeasts

Posted Date: November 2nd, 2020

DOI: https://doi.org/10.21203/rs.3.rs-98363/v1

License: (c) (i) This work is licensed under a Creative Commons Attribution 4.0 International License.

Read Full License 


\section{Abstract}

Microorganisms are now the main sources of industrial enzymes, with fungi and yeasts that have contributed about $50 \%$, bacteria has contributed about $35 \%$, whereas the remaining $15 \%$ are also of phytopathogenic fungi while some are plant parasitic nematodes or animal origin. The prospective of using these microorganisms as sources of biotechnological and industrial relevant enzymes motivated interest in the study of extracellular enzymes from numerous microorganisms which include various fungi, bacteria, actinomycetes and yeasts. The aim of this study was to isolate and screen for mannanase-producing yeasts from citrus wastes and to produce, optimize, purify and characterize the enzyme. One hundred and two (102) yeasts were isolated from different citrus wastes obtained from five different markets and screened for their mannanase producing ability. Gum Arabic was used as a substrate for the production of mannanase enzyme by yeasts isolates using submerged fermentation. Candida sp. LES2, Candida sp. OS12, Pichia sp. and Pichia kudriavzevii (AUMC 10190) were the yeast isolates with the best potential of mannanase production. Incubation period, $\mathrm{pH}$, temperature, carbon and nitrogen source were optimized under submerged fermentation for the production of mannanase. The mannanase produced by Pichia kudriavzevii (AUMC 10190) was optimally active at pH $7.0(202.10 \mathrm{U} / \mathrm{ml}$ ) and its temperature is stable at $60^{\circ} \mathrm{C}$. Pichia kudriavzevii (AUMC 10190) was optimally active at $35^{\circ} \mathrm{C}$ $(147.91 \mathrm{U} / \mathrm{ml})$. Mannanase enzyme produced by Pichia kudriavzevii (AUMC 10190) had a purification fold of 2.14 with a specific activity of $134.53 \mathrm{U} / \mathrm{ml}$ proving that yeasts obtained from citrus wastes have the ability to produce mannanase enzyme under optimized conditions. Therefore, it can be concluded that Pichia kudriavzevii (AUMC 10190) isolated from citrus waste is potential yeast for the production of mannanase under suitable condition for higher yield.

\section{Introduction}

Mannanases from microorganisms are now important biotechnologically as they are involved in the hydrolysis of complex polysaccharides of plant tissues into simple molecules like mannooligosaccharides and mannoses. The importance of mannanases in the paper and pulp industry is well well-known and recently they have also found application in the food and feed technology, coffee extraction, oil drilling and detergent production. Mannanase is commonly produced by bacteria, actinomycetes, fungi, plants, and animals (Adiguzel et al. 2015). Bacterial mannanases are mostly extracellular and act in a wide range of $\mathrm{pH}$ and temperature. However, acidic and neutral mannanases are more common (Dhawan and Kaur 2007).

Yeasts are the least studied group of microorganisms that have the ability to produce mannanase. For these microorganisms, mannanase activity as a component of their lytic complex is more characteristic. However, even among the yeasts, the cultures with high mannanase activity are described, although not as numerous as among bacteria and micromycetes (Dhawan and Kaur 2007; Chauhan et al.2012). The undoubted advantage of yeasts as enzyme producers over other microorganisms is their resistance to infections and they are easy to separate from the culture medium due to large cell sizes. Mannanases have been produced by submerged fermentation in most of the studies (Kote et al. 2009). 
Beta-D-mannanase (mannan endo-1,4-beta- mannohydrolase, EC 3.2.1.78) are hydrolytic enzymes that hydrolyze randomly beta-1,4 mannosidic linkages within the backbones of mannan, galactoglucomannan, glucomannan and galactomannan (Olaniyi and Adebowale 2017). Mannans, in which D-mannose is the main component, are important to many industries for example food, feed, and feed stocks. Mannans could be broken down into simple sugars or oligosaccharides by the combined action of endo-mannanases (EC number 3.2.1.78, mannan endo-1,4-beta-mannosidase) and betamannosidase (EC number 3.2.1.25) (Chantom et al. 2015). Continuous identification and the introduction of new and diverse microbial sources, mainly those which are non-toxic to humans, are of high interest.

Most mannanases are of microbial origin and are extracellular. They act in a wide range of $\mathrm{pH}$ and temperature that is why they have applications in pulp and paper, food, feed, pharmaceutical, oil and textile industries. Microbial mannanases are inducible (Dhawan and Kaur 2007). Galactomannan-rich substrate locust bean gum (LBG) has been used widely as an inducer of $\beta$-mannanase (Kote et al. 2009; Kim et al. 2011a). Other substrates like copra meal, wheat bran and konjac powder, have also been used for the same purpose, since they have important benefit because they are cheap and also in abundant (Zhang et al. 2009; Meenakshi et al. 2010; Rashid et al. 2010). The production of mannanases is affected by nutritional and physicochemical factors such as; incubation time, temperature, $\mathrm{pH}$, carbon and nitrogen sources, inorganic salts, agitation and dissolved oxygen concentration (Aziz et al.2008; Moreira and Filho 2008; Ajibare 2014). Different microorganisms require different incubation times for maximum mannanase production. This study aimed to isolate and screen for yeasts that have the ability to produce mannanase from citrus wastes and to optimize the production of the enzyme.

\section{Materials And Methods}

\section{Yeast Isolation}

Samples were serially diluted in sterile distilled water and plated out using the pour plate method. The media used was Yeast Extract Agar (Oxoid). The media was prepared and sterilized according to Manufacturer's specification. The media was supplemented with glucose and streptomycin to enhance yeast growth and to suppress the growth of bacteria respectively. All plates were incubated at $30^{\circ} \mathrm{C}$ for about 3 to 5 days. Yeast cells were further purified by streaking on fresh plates in order to obtain a pure colony. The pure colonies were examined and identified microscopically. The pure cultures were then stored in Yeast Extract broth and glycerol at $4^{\circ} \mathrm{C}$ for further use (Barnett 2003)

\section{Screening for mannanase producing yeasts}

The isolates were screened for mannanase producing ability by inoculating them in a sterile medium containing $1 \%$ Gum Arabic, $0.1 \%$ yeast extract, $0.1 \%$ peptone, $0.1 \% \mathrm{NH}_{4} \mathrm{NO}_{3}, 0.14 \% \mathrm{KH}_{2} \mathrm{PO} 4,0.02 \% \mathrm{MgCl}_{2}$, $1 \%$ Congo Red and $3 \%$ Agar (Rattanasuk and Ketudat-Cairns 2009). The plates were incubated at $30^{\circ} \mathrm{C}$ for 24 hours, 48 hours and 72 hours. The mannanase activity of each isolate was measured based on the 
ratio of the clearing zone (dark blue-black colouration) formed. The colonies with highest clear zone were collected and maintained as frozen stocks in the presence of $20 \%$ glycerol (Adebayo-Tayo et al. 2013).

\section{Secondary mannanase screening}

The Mannanase Screening Medium (MSM) containing in g/l: Peptone 0.1, yeast extract $0.1, \mathrm{MgCl}_{2} 0.02$, $\mathrm{KH}_{2} \mathrm{PO}_{4} 0.14, \mathrm{NH}_{4} \mathrm{NO}_{3}$ 0.1, and Gum Arabic 1.0, Distilled water 1 liter and $\mathrm{pH} 5.5$ was used. $100 \mathrm{ml}$ of the sterile mannanase production medium was inoculated with $0.5 \mathrm{ml}$ of the isolate after using Mac Farland Standard and incubated for $48 \mathrm{hrs}$. After incubation, the fermentation medium was harvested by centrifugation at $4000 \mathrm{rpm}$ for 30 minutes at $4^{\circ} \mathrm{C}$. The supernatant was used to assay for mannanase activity (Adebayo-Tayo et al. 2013).

\section{Molecular identification of the tolerant strain}

\section{DNA Extraction Protocol}

The extraction of the yeast genomic DNA for molecular analysis was carried out according to the method of Arnold et al. (2011). Colonies of yeast isolates were picked from a Yeast Extract Agar (YEA) plate and was suspended in $100 \mu \mathrm{L} 200 \mathrm{mM} \mathrm{LiOAc} 1 \%$ SDS solution, and incubated at $70^{\circ} \mathrm{C}$ for $15 \mathrm{~min}$. After incubation, $300 \mu \mathrm{L} 96 \%$ ethanol was added and the samples were mixed by brief vortexing. The DNA was collected by centrifugation at $15,000 \times g$ for 3 minutes. Precipitated DNA was dissolved in $100 \mu \mathrm{L}$ TrisEDTA (TE) buffer. The cell debris was spun down by brief centrifugation (15,000× $g$ for $1 \mathrm{~min})$, and $1 \mu \mathrm{L}$ supernatant was used for PCR.

\section{Mannanase production in submerged fermentation}

The Mannanase Production Medium (MPM) containing in g/l: Bacteriological peptone 0.1, yeast extract $0.1, \mathrm{MgCl}_{2} 0.02, \mathrm{KH}_{2} \mathrm{PO}_{4} 0.14, \mathrm{NH}_{4} \mathrm{NO}_{3} 0.1$, and locust bean gum (LBG) 1.0, Distilled water 1 liter and $\mathrm{pH}$ 5.5 was used. $100 \mathrm{ml}$ of the sterile mannanase production medium was inoculated with $0.5 \mathrm{ml}$ of the isolate and incubated for $24 \mathrm{hrs}$. After incubation, the fermentation medium was harvested by centrifugation at $4000 \mathrm{rpm}$ for 30 minutes at $4^{\circ} \mathrm{C}$. The supernatant was used to assay for mannanase activity (Adebayo-Tayo et al. 2013).

\section{Mannanase assay and protein determination}

The mannanase activity was assayed by measuring the reducing sugars using dinitrosalicylic acid (DNSA) method (Miller 1959). An assay mixture containing $0.5 \mathrm{ml}$ of the culture supernatant and $0.5 \mathrm{ml}$ of $0.5 \%(\mathrm{w} / \mathrm{v})$ Locust bean gum (LBG) in $0.05 \mathrm{M}$ phosphate buffer at $\mathrm{pH} 5.5 .0$ was incubated at $50^{\circ} \mathrm{C}$ for 
$30 \mathrm{~min}$. After incubation, $1 \mathrm{ml}$ of reagent was added and boiled for $5-15 \mathrm{~min}$. The developed red brown color was measured at $575 \mathrm{~nm}$. The amount of reducing sugar released was determined by the dinitrosalicylic acid (DNSA) method (Miller 1959). One unit of mannanase activity was defined as amount of enzyme producing 1 micromole of mannose per minute under the experimental conditions. The amount of protein produced in the basal medium was also determined by the method of Lowry et al 1951 using Bovine Serum Albumin (BSA) as the standard.

\section{Optimization of the cultural parameters in submerged fermentation}

The basal medium was optimized with various factors that influence the mannanase production. The various physicochemical parameters of fermentation were optimized which included; temperature, $\mathrm{pH}$, incubation time, incubation temperature, carbon sources and nitrogen sources.

\section{Effect of Temperature}

The effect of temperature on mannanase production using submerged fermentation was carried out at different temperatures. This was done between the range of $(25,30,35,40$, and 45$){ }^{\circ} \mathrm{C}$ (Adebayo-Tayo et al. 2013; Oskay and Yalcin 2014).

\section{Effect of $\mathrm{pH}$}

The effect of $\mathrm{pH}$ on enzyme production was also carried out. $\mathrm{pH}$ values ranging from $(4,5,6,7$ and 8$)$ was used to investigate the effect of $\mathrm{pH}$ on the production of mannanase. Acetate, citrate and phosphate buffer were the buffers of choice used in this experiment (Adebayo-Tayo et al. 2013; Oskay and Yalcin 2014).

\section{Effect of Incubation time}

The production enzyme for mannanase were harvested at different incubation time $(24,48$, and 72$)$ hours and assayed to determine the best time that supports enzyme production (Adebayo-Tayo et al. 2013; Oskay and Yalcin 2014).

\section{Effect of nitrogen sources}

To investigate the effect of the different nitrogen sources on mannanase production, the only nitrogen sources in the basal medium which was peptone and yeast extract were replaced by different nitrogen 
sources such as Urea, casein, ammonium sulphate, ammonium chloride and yeast extract/peptone(1:1) at1\% (w/v) concentrations (Adebayo-Tayo et al. 2013; Oskay and Yalcin 2014).

\section{Effect of carbon sources}

The effect of various carbon sources such as glucose, fructose, sucrose, maltose and mannitol at $1 \%$ $(\mathrm{w} / \mathrm{v})$ concentrations was also carried out in addition to gum arabic which was the sole source of carbon in the basal medium (Adebayo-Tayo et al. 2013; Oskay and Yalcin 2014).

\section{Purification of enzyme}

\section{Ammonium Sulphate $\left(\mathrm{NH}_{4} \mathrm{SO}_{2}\right)$ Precipitation}

After determining the percentage saturation of ammonium sulphate salts that gave the highest activity, the equivalent amount of salt for 1 litre of crude enzyme was added. The salt was allowed to dissolve completely and the mixture was allowed to stand for $30 \mathrm{hrs}$ at $4^{\circ} \mathrm{C}$. It was then centrifuged at $4000 \mathrm{rpm}$ for 30 minutes. The pellets were collected and stored in a cool place for further studies (Khairnar et al. 2009).

\section{Dialysis}

Dialysis tubes stored in $90 \%$ ethanol were used. The tubes were rinsed thoroughly with distilled water and finally with $0.05 \mathrm{M}$ phosphate buffer in order to remove traces of ethanol. An amount of the precipitated enzyme was poured into the dialysis tubes and placed in a beaker containing $0.05 \mathrm{M}$ phosphate buffer. The beaker was placed on a magnetic stirrer which allows for a homogenous environment. The dialysis was carried out according to Dixon and Webb (1964) for 12 hours and the buffer is changed after 6 hours which allows for the exchange of low molecular weight substances and left over ammonium sulphate salts that may interfere with the activity. After dialysis, mannanase activity was measured in each fraction applying DNS method: $0.5 \mathrm{ml}$ of dialysed partially purified enzyme was added to $0.5 \mathrm{~mL}$ gum arabic $1 \%(\mathrm{w} / \mathrm{v})$ in $0.05 \mathrm{M}$ phosphate buffer $(\mathrm{pH} 6.0)$ separately. Test tubes were covered and incubated for $5 \mathrm{mins}$ at $65^{\circ} \mathrm{C}$ in a water bath. Then, $1 \mathrm{~mL}$ DNS reagent was added to each tube to stop the reaction and placed in boiling water bath for 5 mins. After cooling the samples in a cold water bath, the absorbance was read at $540 \mathrm{~nm}$ (Khairnar et al. 2009).

\section{Gel-filtration chromatography}

Mannanase was purified to homogeneity by the gel-filtration chromatography. The dialysed enzyme was loaded on the gel permeation column (Sephadex G-25). All the eluted fractions were estimated for 
enzyme activity and absorbance was read at $540 \mathrm{~nm}$ and $575 \mathrm{~nm}$ respectively. The fractions showing the highest enzyme activity were pooled and assayed for protein content. The specific activity of purified enzyme fractions was compared to that of crude enzyme and fold purification was calculated (Sharma et al. 2005).

\section{Characterization of partially purified mannanase enzyme}

\section{Effect of pH Change on Mannanase Activity}

The effect of $\mathrm{pH}$ on enzyme activity was determined using $0.05 \mathrm{M}$ sodium acetate buffer $\mathrm{pH} 3.5-5.5$, phosphate buffer $\mathrm{pH} 6.0-7.5$ and Tris-HCl buffer $\mathrm{pH} 8.0-10.0$ at intervals of 1.0. $0.1 \%$ gum arabic solution was prepared by dissolving $0.1 \mathrm{~g}$ gum arabic in $100 \mathrm{ml}$ of $0.05 \mathrm{M}$ of the respective buffers separately. Also $0.5 \mathrm{ml}$ of the partially purified enzyme was added to $0.5 \mathrm{ml}$ of each of the buffers. Then ultimately, $0.5 \mathrm{ml}$ of the enzyme-buffer solution was mixed with $0.5 \mathrm{ml}$ gum arabic solution at the corresponding pH for mannanase assay as described previously (Adebayo-Tayo et al. 2013; Oskay and Yalcin 2014).

\section{Effect of Temperature Change on Mannanase Activity}

The optimum temperature was determined by incubating the enzymes with gum arabic solution at 35$50^{\circ} \mathrm{C}$ interval of $5^{\circ} \mathrm{Cfor} 1 \mathrm{hour}$ and at the $\mathrm{pH}$ with the highest activity. The activity was then determined as described previously (Adebayo-Tayo et al. 2013; Oskay and Yalcin 2014).

\section{Effect of Substrate Concentration on Mannanase Activity}

The effect of substrate concentration on the activity of mannanase was determined by incubating the enzyme with 0.5 up to $2.0 \mathrm{mg} / \mathrm{ml}$ gum arabic at an interval of 0.5 using the buffer at the $\mathrm{pH}$ with highest activity and the temperature at which highest activity was determined (Adebayo-Tayo et al.,2013; Oskay and Yalcin 2014).

$\mathrm{Km}$ and Vmax were determined by incubating the enzyme with varying concentrations of substrate. The results were plotted as a graph of rate of reaction ( $v$ ) against concentration of substrate[S].

The relationship is defined by the Michaelis-Menten equation:

$\mathrm{v}=\operatorname{Vmax} /(1+(\mathrm{Km} /[\mathrm{S}])$

\section{Thermal Stability of Mannanase}


For thermal stability, the partially purified enzyme was pre-incubated for $1 \mathrm{~h}$ at various temperatures (50, $60,70,80,90)^{\circ} \mathrm{C}$ before enzyme assay, and promptly cooled on ice and residual activity was determined under standard assay conditions.

\section{Statistical Analysis}

Each of the $\beta$-mannanase activity experiment was done in triplicate and expressed as mean $\pm S D$ (standard deviation) using SPSS and analysis of variance (ANOVA) was used to compare various treatment groups.

\section{Results}

\section{Screening for Mannanase producing yeasts isolated from citrus wastes}

All the isolates were screened for mannanase production. Thirty-one isolates showed mannanase degrading ability. Secondary screening was carried out for isolates with the highest zones of clearance. Ten yeast isolates showed the highest zones of clearance, therefore, four most promising isolates were selected for the production of mannanase. These four isolates with the code OS8, LeA5, OS12 and LeS2 showed mannanase activity of $121.10 \mathrm{U} / \mathrm{ml}, 155.50 \mathrm{U} / \mathrm{ml}, 138.50 \mathrm{U} / \mathrm{ml}$ and $107.60 \mathrm{U} / \mathrm{ml}$ respectively and production using submerged fermentation. The four best isolates were selected based on secondary screening for further studies.

\section{Optimization of fermentation parameters}

The production of mannanase enzyme by the yeast isolates Pichia sp. , Pichia kudriavzevii (AUMC 10190), Candida sp.0S12, Candida sp. LeS2 were affected by several factors which include the following parameters; incubation time, temperature, carbon sources, nitrogen sources and $\mathrm{pH}$ under submerged fermentation.

\section{Effect of incubation period}

Mannanase production by all the yeast isolates increased as incubation period increased but was optimum at 48 hours. Mannanase production by Candida sp. $0 S 12$ was $130.20 \mathrm{U} / \mathrm{ml}$ and Pichia kudriavzevii (AUMC 10190) with the highest production of $138.02 \mathrm{U} / \mathrm{ml}$ (figure 1) were found to be the highest after 48 hours of incubation.

\section{Effect of temperature on enzyme production}


Mannanase production by Saccharomyces sp. OS8, Pichia kudriavzevii (AUMC 10190), Candida sp. OS12, Candida sp. LeS2 was found to be optimal at an incubation temperature of $30^{\circ} \mathrm{C}$ and $35^{\circ} \mathrm{C}$. The values at the optimal temperature which is $35^{\circ} \mathrm{C}$ are $136.02 \mathrm{U} / \mathrm{ml}$ for Saccharomyces sp. OS8, $147.91 \mathrm{U} / \mathrm{ml}$ for Pichia kudriavzevii (AUMC 10190), 110.03U/ml for Candida sp. LeS2 and $141.01 \mathrm{U} / \mathrm{ml}$ for Candida sp. OS12. Therefore, Pichia kudriavzevii (AUMC 10190) gave the highest production of $147.91 \mathrm{U} / \mathrm{ml}$ at $35^{\circ} \mathrm{C}$ (figure 2) which is the optimal temperature.

\section{Effect of pH on enzyme production}

The $\mathrm{pH}$ value of the fermentation medium for the production of mannanase enzyme is an important factor. For mannanase production, the optimal pH for Saccharomyces sp. OS8 was 5 with a value of $152.07 \mathrm{U} / \mathrm{ml}$ while the optimal $\mathrm{pH}$ for Saccharomyces sp.LEA5 was 7 with a value of $202.10 \mathrm{U} / \mathrm{ml}$ as the enzyme produced after 48 hours. Therefore, Saccharomyces sp. OS8 and Pichia kudriavzevii (AUMC 10190) gave the highest enzyme production at pH 5 and 7 respectively after 48 hours (figure 3 ).

\section{Effect of carbon sources on enzyme production}

The effect of different carbon sources on the production of mannanase enzyme was studied. It was observed that mannanase production by Pichia kudriavzevii (AUMC 10190) after 48 hours gave the highest production when the medium was supplemented with glucose with a value of $144.26 \mathrm{U} / \mathrm{ml}$. Candida sp. OS12 also had its highest value $(139.19 \mathrm{U} / \mathrm{ml})$ when the medium was supplemented with fructose (figure 4).

\section{Effect of nitrogen sources on enzyme production}

The effect of different nitrogen sources on the fermentation medium was also studied. After 48 hours, optimal mannanase production was observed by Pichia kudriavzevii (AUMC 10190) when the medium was supplemented with ammonium nitrate $\left(\mathrm{NH}_{4} \mathrm{NO}_{3}\right)$ and peptone showing different values of $226.1 \mathrm{U} / \mathrm{ml}$ and $177.02 \mathrm{U} / \mathrm{ml}$ respectively while Candida sp. OS12 showed different values of $165.5 \mathrm{U} / \mathrm{ml}$ and $128.0 \mathrm{U} / \mathrm{ml}$ (figure 5 ) when the medium was supplemented with ammonium sulphate $\left(\mathrm{NH}_{4} \mathrm{SO}_{4}\right)$ and peptone.

\section{Purification of enzyme}

After all the purification steps were complete, the specific activity of mannanase enzyme by Pichia kudriavzevii (AUMC 10190) was 134.53U/ml with a purification fold of 2.14. Table 1 summarizes the effect of each purification step on the activity of mannanase enzyme produced by Pichia kudriavzevii (AUMC 10190) respectively. The activity increases progressively as each purification step was carried out. 
Table 1

Enzyme yield and Purification fold of mannanase produced from Pichia kudriavzevii (AUMC 10190)

\begin{tabular}{|lllllll|}
\hline $\begin{array}{l}\text { Purification } \\
\text { steps }\end{array}$ & $\begin{array}{l}\text { Total } \\
\text { volume } \\
(\mathrm{mL})\end{array}$ & $\begin{array}{l}\text { Total enzyme } \\
\text { activity }(\mathrm{U} / \mathrm{mL})\end{array}$ & $\begin{array}{l}\text { Total protein } \\
(\mathrm{mg} / \mathrm{mL})\end{array}$ & $\begin{array}{l}\text { Specific } \\
\text { activity } \\
(\mathrm{U} / \mathrm{mg})\end{array}$ & Fold & Yield \\
\hline Crude & 50 & 2924 & 46.43 & 62.97 & 1 & 100 \\
\hline $\begin{array}{l}\text { Ammonium } \\
\text { sulphate }\end{array}$ & 50 & 2808 & 38.09 & 73.72 & 1.17 & 96.03 \\
\hline Dialysis & 10 & 879 & 11.20 & 78.48 & 1.25 & 30.06 \\
\hline Gel filtration & 5 & 487 & 3.62 & 134.53 & 2.14 & 16.66 \\
\hline
\end{tabular}

\section{Characterization of crude mannanase enzyme}

\section{Optimum temperature for stability of crude mannanase}

The effect of temperature on crude mannanase stability was determined by exposing the enzyme to various temperatures ranging from $50^{\circ} \mathrm{C}-90^{\circ} \mathrm{C}$ for 30 minutes. The activity of mannanase enzyme by the yeast isolate Pichia kudriavzevii (AUMC 10190) gradually dropped above $60^{\circ} \mathrm{C}$ (figure 6).

\section{Optimum pH for stability of crude mannanase}

The effect of different $\mathrm{pH}$ on mannanase activity was determined by exposing the crude enzyme to different $\mathrm{pH}$ from $\mathrm{pH} 4-8$ at $50^{\circ} \mathrm{C}$ for 30 minutes. Results indicate that optimum mannanase activity was observed at a pH level of 7 for Pichia kudriavzevii (AUMC 10190) (120.U/ml) (figure 7).

\section{Optimum substrate concentration for mannanase activity}

The effect of substrate concentration on the activity of enzyme was studied by determining the activity at different concentrations $(0.5 \%-2.0 \% \mathrm{w} / \mathrm{v})$. Results show that mannanase activity by Pichia kudriavzevii (AUMC 10190) was optimal at a substrate concentration of $0.5 \%$ with a value of $108.7 \mathrm{U} / \mathrm{ml}$ (figure 8 ).

\section{Discussion}

In this study, one hundred and two (102) yeast isolates were obtained from different citrus wastes (lemon, lime, orange and grape). After preliminary screening of the one hundred and two (102) isolates for their enzyme producing ability, thirty-one (31), which represented $30 \%$ of the total, were positive for 
mannanase producing ability. This was almost similar to the report of Ernesto et al. (2006) and ObinnaEchem et al. (2014).

The factors that affect mannanase production are temperature, incubation time, $\mathrm{pH}$ nitrogen sources and carbon sources. In this study, it was observed that after 48 hours of fermentation, there was accumulation of maximum extracellular enzyme. This is in accordance with the study of Oskay and Yalcin (2014) who also reported 48hours as the best incubation time for maximum mannanase production by yeasts. The period of fermentation is influenced by the nature of medium, concentration of nutrients, fermenting organisms, and the physiological conditions (Patil and Dayanand 2006).

A temperature of $35^{\circ} \mathrm{C}$ and $\mathrm{pH}$ 5.0-6.0 were the optimum parameters for mannanase production. This is in line with the work of Oskay and Yalcin (2014) and Adebayo-Tayo et al. (2013) who reported similar temperature and $\mathrm{pH}$ for mannanase production.

In this study, the substrate used for the production of extracellular mannanase was gum Arabic. Substrates should provide all needed nutrients to the microorganism for its growth. Although a decreased level in the production of mannanase was observed when gum Arabic was supplemented with additional carbon sources. Mannanase production was carried out using gum arabic as substrate, but the optimal production was observed when the medium was supplemented with glucose as an external source of carbon. This was not in accordance with the work of Adebayo-Tayo et al. (2013) who reported that fructose as an external source of carbon was optimum for mannanase production by Bacillus species because they worked on bacteria. These observations were however in conformity with the suggestion of How and Ibrahim (2004) who suggested that there is need to supplement mannanase substrate with other carbon sources because the substrates are derived from the degradation of organic compounds which may not be enough to supplement microbial growth fully.

Nitrogen source is one of the most important in microbial growth because it plays a major role in the biosynthesis of cell metabolites and general maintenance of physiology of the cells. In this study, ammonium nitrate was the best source of nitrogen for mannanase production, which was also in line with the work of Oskay and Yalcin (2014). However this was in contrast with the work of Hoa and Hung, (2013) who reported urea as the best nitrogen source and also Adebayo-Tayo et al. (2013) who reported ammonium sulphate and urea as the best nitrogen source for the production of mannanase by some other microorganisms. In this research, submerged fermentation technique was applied due to the fact that temperature, $\mathrm{pH}$, moisture, substrate concentration during cultivation would have been difficult to control under limited water availability (Holker et al. 2004). Submerged liquid fermentation is the cultivation of microorganisms in liquid nutrient broth. Submerged fermentation involves growing carefully selected microorganisms (bacteria and fungi) in closed vessels containing a rich broth of nutrients (the fermentation medium) and a high concentration of oxygen (GrigelmoMigeul and MartinBelloso 1998).

During purification of the enzyme, mannanase, after the protein was precipitated, dialysis was carried out to remove excess salt. It also changes the buffer composition of solutions of biomolecules which maybe 
too large to pass through the membrane during gel filtration chromatography (Olaniyi et al 2014). Therefore, it was observed that there was a decrease in volume of about $5 \mathrm{ml}$ of the enzyme after dialysis. This may be due to the further separation that occurred between the low and high molecular weight proteins that were initially present (Olaniyi et al 2014)

There was increase in the activity of mannanase after precipitation and subsequently after dialysis. This agrees with the suggestion of Lukong et al. (2007) who suggested that increase in enzyme activity may have occurred due to the removal of impurities (such as other proteins) during dialysis. The activity peaks obtained from the elution profile could be attributed to the source of isolation coupled with environmental influences

The partially purified enzyme was characterized based on the effect of change in $\mathrm{pH}$, temperature and substrate concentration. The optimal $\mathrm{pH}$ for the activity of mannanase was 7.0, which was not in accordance with the work of Jiang et al. (2006) who reported pH 6.0 for Bacillus subtilis. This was however in agreement with the report of Zakaria et al. (1998) and Meenakshi et al. (2010) who reported $\mathrm{pH} 7.0$ for optimal mannanase production.

Temperature has effect in the activity of mannanase. The activity of mannanase enzyme produced by Pichia kudriavzevii (AUMC 10190) was optimum at $60^{\circ} \mathrm{C}$ but was still stable throughout the different temperature ranges. This would be an indication of the thermo stability of the enzyme.

The partially purified mannanase was subjected to different substrate concentrations (0.5$2.0 \%$ w/v). Mannanase activity however by Pichia kudriavzevii (AUMC 10190) was optimum at the lowest substrate concentration. According to Anosike (2001), $\mathrm{K}_{\mathrm{m}}$ values provide a parameter for comparing enzymes from different organisms. With the knowledge of Michaelis Menten, it is known that a small $\mathrm{K}_{\mathrm{m}}$ indicates that the enzyme requires only a small amount of substrate to become saturated; hence, the maximum velocity is reached at relatively low substrate concentration.

\section{Conclusions}

In this study, it was shown that yeast isolates obtained from citrus wastes (Lemon, Orange, Lime, Grape) particularly Pichia kudriavzevii (AUMC 10190) yielded high activity of mannanase enzyme when supplied with adequate nutritional and optimized conditions. Gum arabic as a substrate for mannanase production is not sufficient as there is need for supplementation with an external source of carbon and nitrogen for adequate enzyme production. Optimum incubation period, temperature and $\mathrm{pH}$ for mannanase production were $48 \mathrm{hours}, 35^{\circ} \mathrm{C}$ and $5.0-6.0$ respectively. Glucose, in combination with gum arabic was the best carbon source, while Ammonium nitrate $\left(\mathrm{NH}_{4} \mathrm{NO}_{3}\right)$ was the preferred source of nitrogen. Partially purified mannanases were stable at high temperatures which indicate the possibility of being used in the industry. Pichia kudriavzevii (AUMC 10190) showed a potential to convert substrates that contain mannan into simple carbohydrates which could be readily used in many industrial applications such as animal foods and a feed stock for production of prebiotics. 


\section{Abbreviations}

MSM: Mannanase screening medium; LBG: Locust bean gum; MPM: Mannanase production medium

\section{Declarations}

\section{Ethics approval and consent to participate}

Not applicable

\section{Consent for publication}

Not applicable.

\section{Availability of data and materials}

All data generated or analysed in this study are included in the published article and are available from the corresponding authors on reasonable request.

\section{Competing interests}

The authors declare that they have no competing interests.

\section{Funding}

The expenses were paid by the authors

\section{Authors' contributions}

FTA designed this research work and YZJ performed the experiments. FTA guided and supervised the research work. YZJ wrote the first draft and analyzed the result. FTA read the manuscript for correction. All authors read and approved the final manuscript.

\section{Acknowledgements}

Not applicable

\section{Author's information}


1,2 Department of Microbiology, Faculty of Science, University of Ibadan, Ibadan, Nigeria

\section{References}

1. Adebayo-Tayo B, Elelu T, Akinola G, Oyinloye, I. (2013) Screening and production of Mannanase by Bacillus strains isolated from fermented food condiments. Innov Romanian Food Biotechnol.13: 5362.

2. Adiguzel G, Sonmez Z, Adiguzel A, Nadaroglu H. (2016) "Purification and characterization of a thermostable endo-beta-1,4 mannanase from Weissella viridescens LB37 and its application in fruit juice clarification," European Food Res Technol. 242(5) 769-776.

3. Ajibare AO. (2014) Assessment of physico-chemical parameters of waters in llaje Local Government Area of Ondo State, Nigeria. Int J Fishery and Aquatic Studies. (5):84-92

4. Anosike EO. (2001) Basic Enzymology. University of Port Harcourt Press. 11-87.

5. Arnold K, Kersti K, Marko L. (2011) Extraction of genomic DNA from yeasts for PCR-based Applications. Biotechniques. 50(5):325-328

6. Aziz SA, Ong LGA, Hassan MA, Karim MIA. (2008) Production parameters optimization of mannanse production from Aspergillus nigerFTCC 5003 using palm kernel cake as carbon source. Asian J Biochem. 3(5): 297-307

7. Barnett JA. (2003) Beginnings of Microbiology and Biochemistry: the contribution of yeast research. Microbiology Reading Engl 149 (3): 557-567.

8. Chantorn S, Pongsapipatana N, Keawsompong S, Ingkakul A, Haltrich D, Nitisinprasert S. (2013) Characterization of mannanase S1 from Klebsiella oxytoca KUB-CW2-3 and its application in copra hydrolysis. Science Asia. 39:236-245.

9. Chauhan A, Zubair S, Sherwani A, Quamar Z, Saba T, Owais M, Sajid M. (2012) Biomimetic assemblage of nucleobase-5-fluorouracil into nano-size. J Biotechnol. 165:421-437

10. Dhawan S, Kaur J. (2007) Microbial mannanases: an overview of production and applications. Critical Rev Biotechnol. 27(4):197-216

11. Dixon M, Webb EG. (1964). Enzymes, 2nd Edit. Academic Press. Inc. New York. Ernesto J, FavelaTorres C, Tania Volke B, Viniegra- González D. (2006). Food Technol Biotechnol. 44 (2): 221-227.

12. Grigelmo-Migeul, Martin-Belloso O. (1998) Characterization of dietary fiber from orange juice extraction. Food Resources Int. 31: 355-361.

13. Hoa BT, Hung PV. (2013) Optimization of nutritional composition and fermentation conditions for cellulase and pectinase production by Aspergillus oryzae using response surface methodology. Int Food Res Journal. 20: 3269-3274.

14. Holker U, Hofer M, Lenz J. (2004) Biotechnological advantages of laboratory-scale solid state fermentation with fungi. Appl Microbiol Biotechnol. 64: 175-186.

15. How SP, Ibrahim CO. (2004) Selection and optimization of lipase production from Aspergillus flavus USM A10 in solid state fermentation (SSF) on rice husks and wood dusts as substrates. Pakistan J 
Biological Sci. 7: 1249-1256.

16. Jiang ZQ, Wei Y, Li D, Li L, Chai P, Kusakabe I. (2006) High-level production, purification and characterization of a thermostable $\beta$-mannanase from the newly isolated Bacillus subtilis WY34.Carbohyd. Poly. 66: 88-96.

17. Khairnar Y, Krishna K, Boraste A, Gupta N. (2009) Study of pectinase production in submerged fermentation using different strains Aspergillus niger. Int J Microbiol Res. 1: 13-17.

18. Kim DY, Ham SJ, Lee HJ, Cho HY, Kim JH, Kim YJ, Shin DH, Rhee YH, Son KH, Park (2011a) Cloning and characterization of a modular GH5 $\beta-1,4-m a n n a n a s e$ with high spec activity from the fibrolytic bacterium Cellulosi microbium sp. strain HY-13. Bioresources Techno. 102:9185-9192.

19. Khairnar Y, Krishna K, Boraste A, Gupta N. (2009). Study of pectinase production in submerged fermentation using different strains Aspergillus niger. Int J Microbiol Res. 1: 13-17.

20. Kote NV, Patil AGG, Mulimani VH. (2009) Optimization of the production of thermostable endo- $\beta-1,4$ mannanase from a newly isolated Aspergillus niger gr. and Aspergillus flavus gr.Appl Biochem Biotechnol. 152:213-223.

21. Lowry OH, Rosebrough NJ, Farr AL. (1951) Randall RJ. Protein Measurement with the Folin Phenol Reagent. J Biol Chem. 193:265-275.

22. Lukong BC, Awah FM, Nwuke CP, Fobellah AD. (2007) Protein Isolation, Purification and Estimation. In: Introduction to Protein Science. OSPREY Publication Centre, Owerri, Pp 55-56.

23. Meenakshi Singh G, Bhalla A, Hoondal GS. (2010) Solid state fermentation and characterization of partially purified thermostable mannanase from Bacillus sp. MG-33. Bioresources 5(3):1689- 1701

24. Miller GL. (1959) Use of dinitrosalicylic acid reagent for determination of reducing sugar. Analytical Chem. 31: 426-428.

25. Moreira LRS, Filho EXF. (2008) An overview of mannan structure and mannan degrading enzyme systems. Appl Microbiol Biotechnol. 79(2):165-178

26. Obinna-Echem PC, Kun V, Beal J. (2014) Evaluation of the microbial community, acidity and proximate composition of Akamu; a fermented maize food. J Science Food Agriculture. 94: 331340.

27. Olaniyi 00, Arotupin DJ, Akinyele BJ. (2014) Kinetic properties of purified $\beta$ - mannanas from Penicillium italiticum. British Microbiol Res Journal. 4(10):1092-1104.

28. Oskay M, Yalcin HT. (2014) Screening of yeast strains for pectinolytic activity: Effects of different carbon and nitrogen sources in submerged fermentations. Online J Biol Sci. 15(3): 89-96.

29. Patil SR, Dayanand A. (2006) Production of pectinase from deseeded sunflower head by Aspergillus niger in submerged and solid-state conditions. Bioresource Technol. 97: 2054-2058.

30. Rashid SA, Darah I, Omar IC. (2010) Utilization of palm kernel cake for the production of mannanase by an indigenous filamentous fungus, Aspergillus niger USM F4 under solid state fermentation. Int Microbiol 9:1 
31. Rattanasuk S, Cairns MK. (2009) Chryseobacterium indologenes novel mannanase-producing bacteria. J Sci Technol. 31 (4):395-399

32. Sharma N, Rathore M, Sharma M. (2005) Microbial pectinase: Sources, characterization and applications. Environmental Sci Biotechnol. 12: 45-60.

33. Zakaria MM, Yamamoto S, Yagi T. (1998) Purification and characterization of an endo1,4- $\beta$ mannanase from Bacillus subtilis KU-1. FEMS Microbiol. Lett. 158: 25-31.

34. Zhang M, Chen XL, Zhang ZH, Sun CY, Chen LL, He HL, Zhou BC, Zhang YZ. (2009) Purification and functional characterization of endo- $\beta$-mannanase MAN5 and its application in oligosaccharides production from konjac flour. Appl J Microbiol Biotechnol. 83:865-873

\section{Figures}

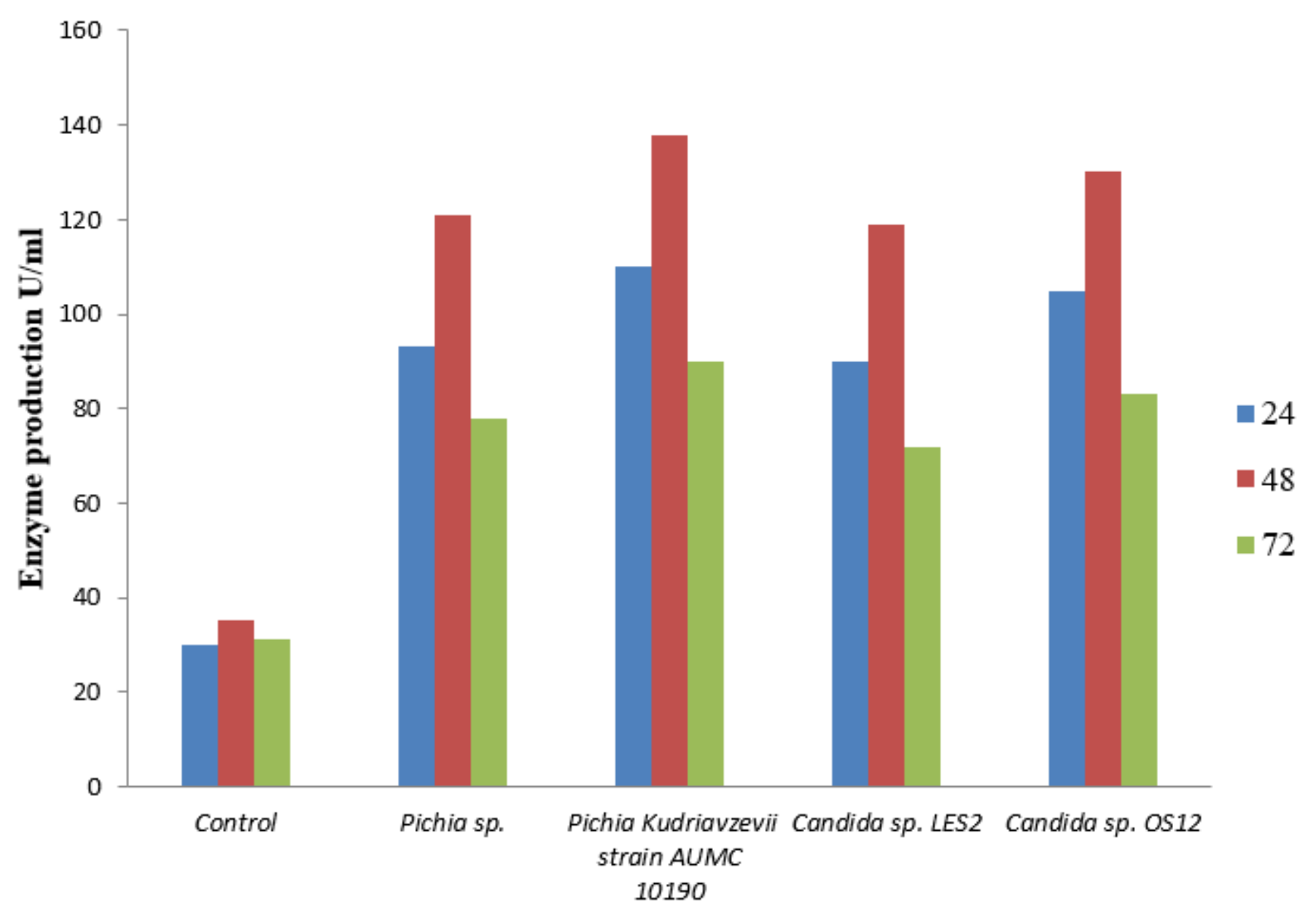

\section{Figure 1}

Effect of incubation time on the production of mannanase by yeast isolates obtained from citrus wastes 


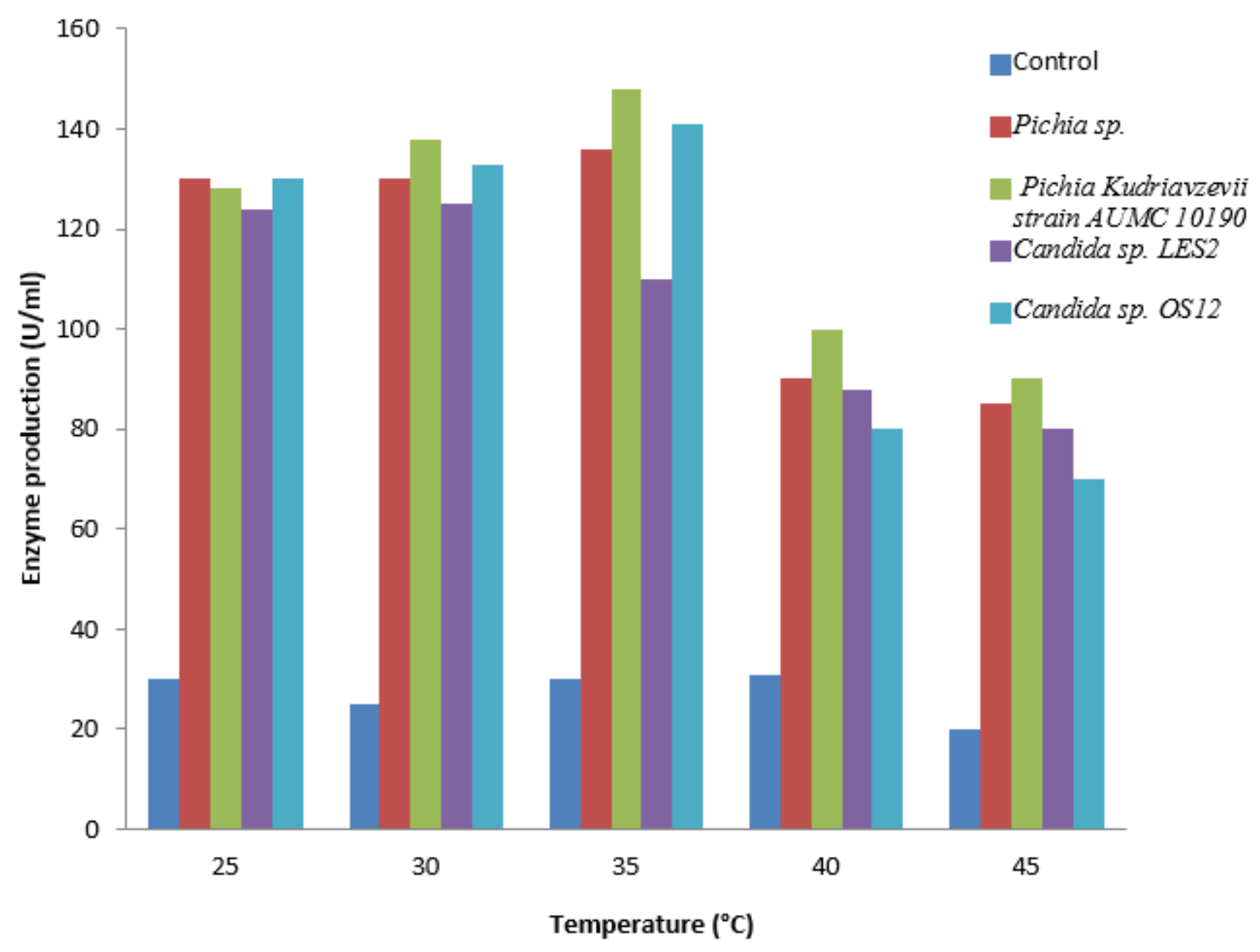

Figure 2

Effect of Temperature on the production of mannanase by yeast isolates obtained from citrus wastes 


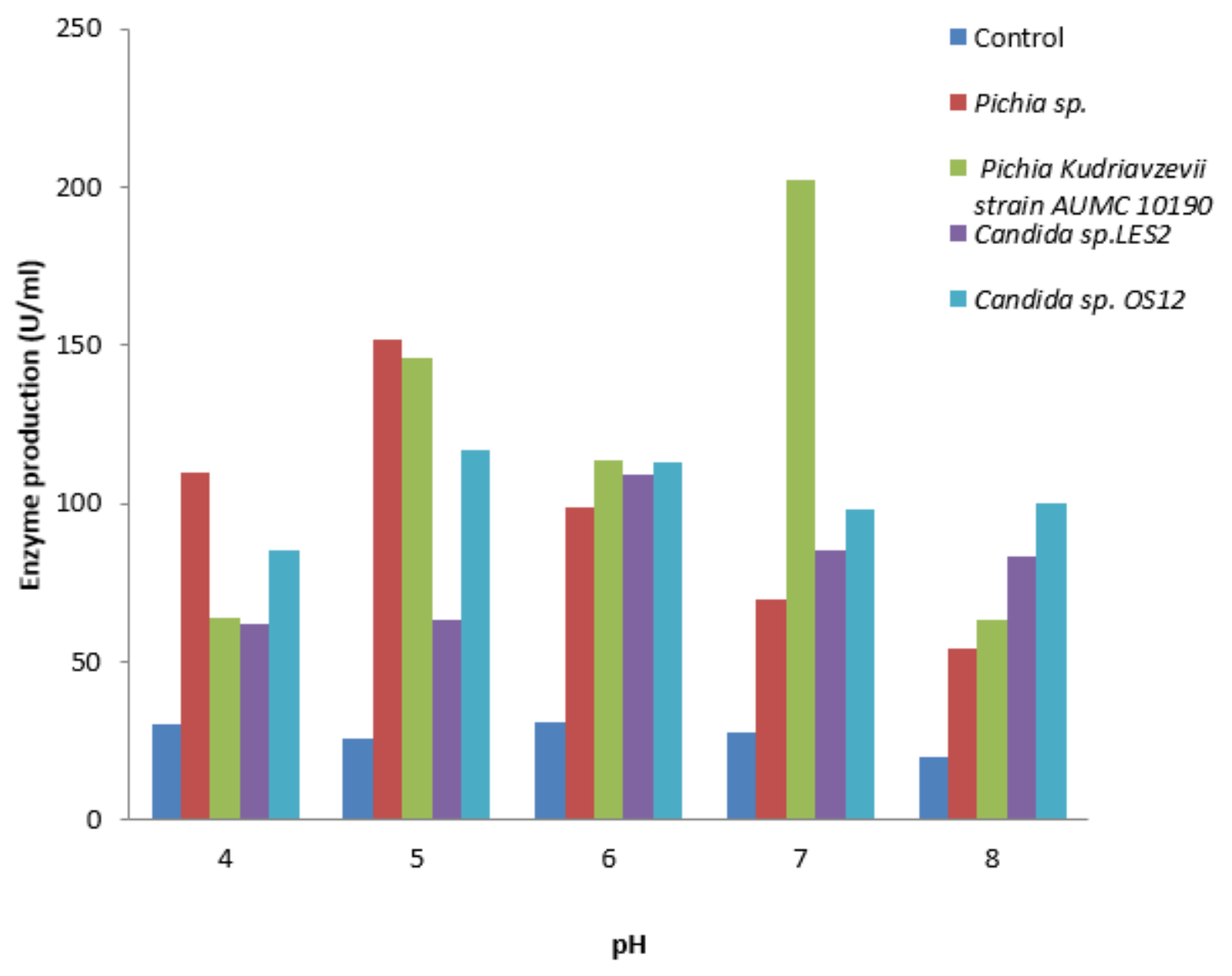

Figure 3

Effect of different $\mathrm{pH}$ on the production of mannanase by yeast isolates obtained from citrus wastes 


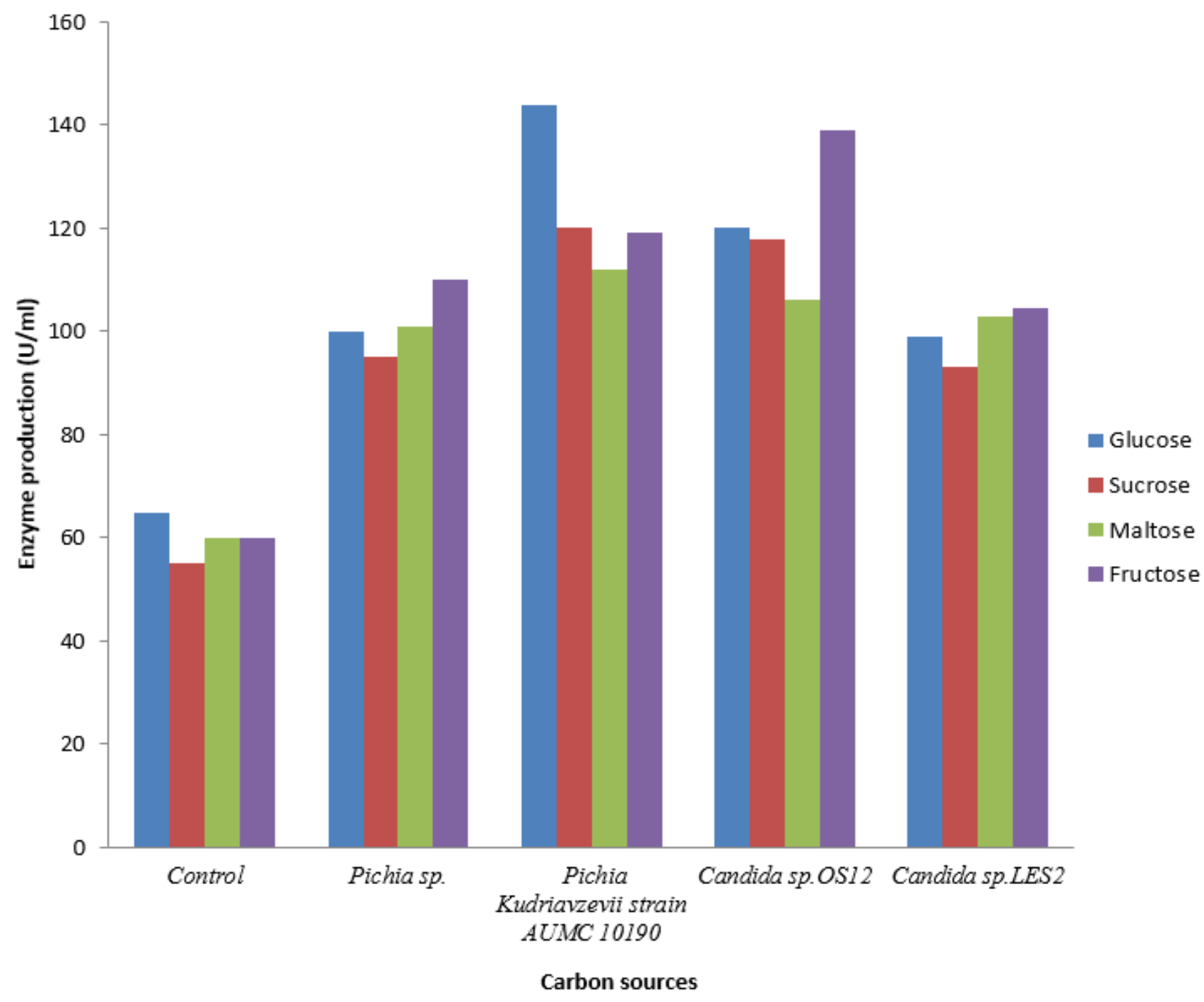

Figure 4

Effect of different Carbon source on the production of mannanase by yeast isolates obtained from citrus wastes 


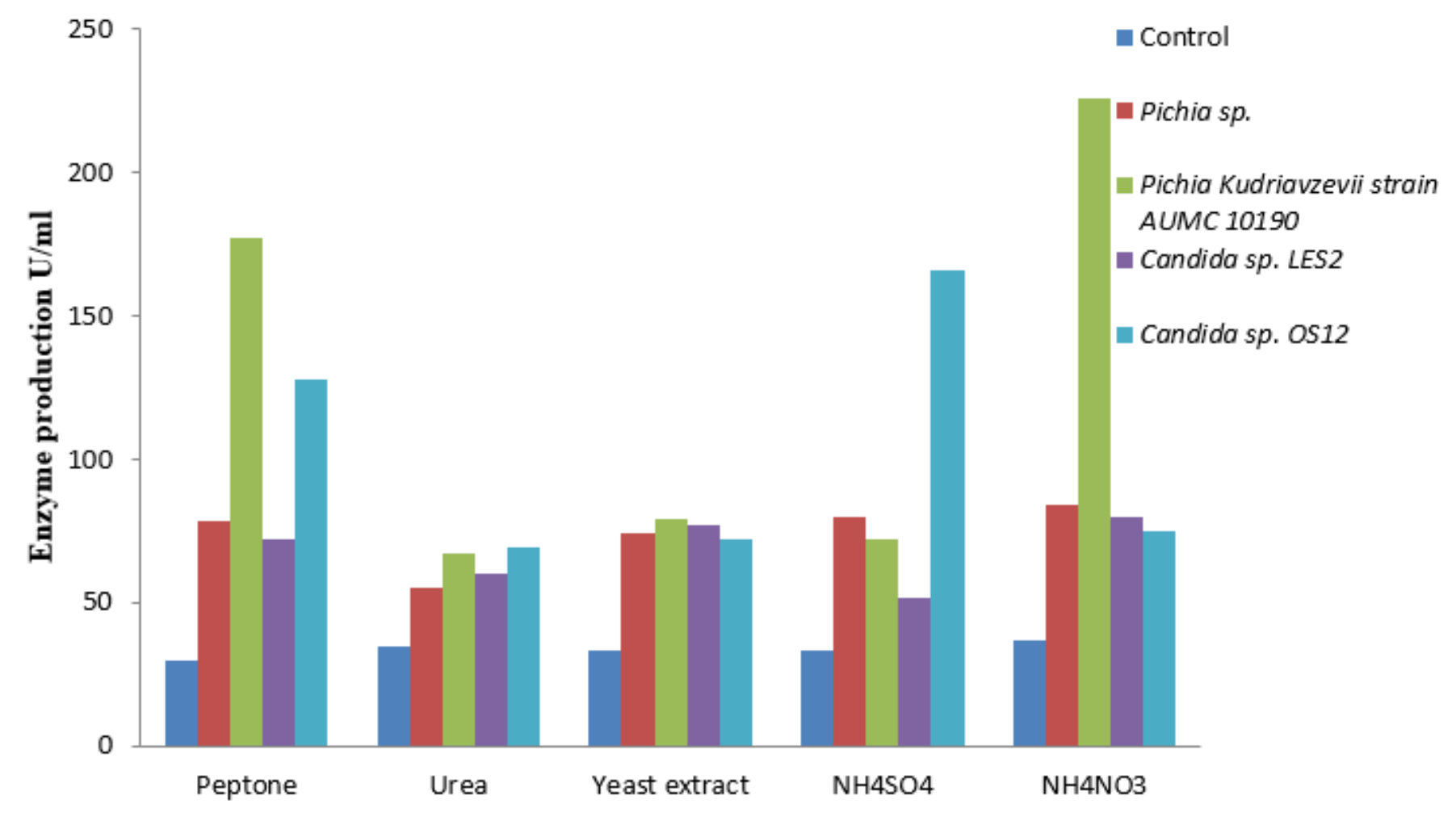

Nitrogen sources

Figure 5

Effect of nitrogen source on the production of mannanase by yeast isolates obtained from citrus wastes 


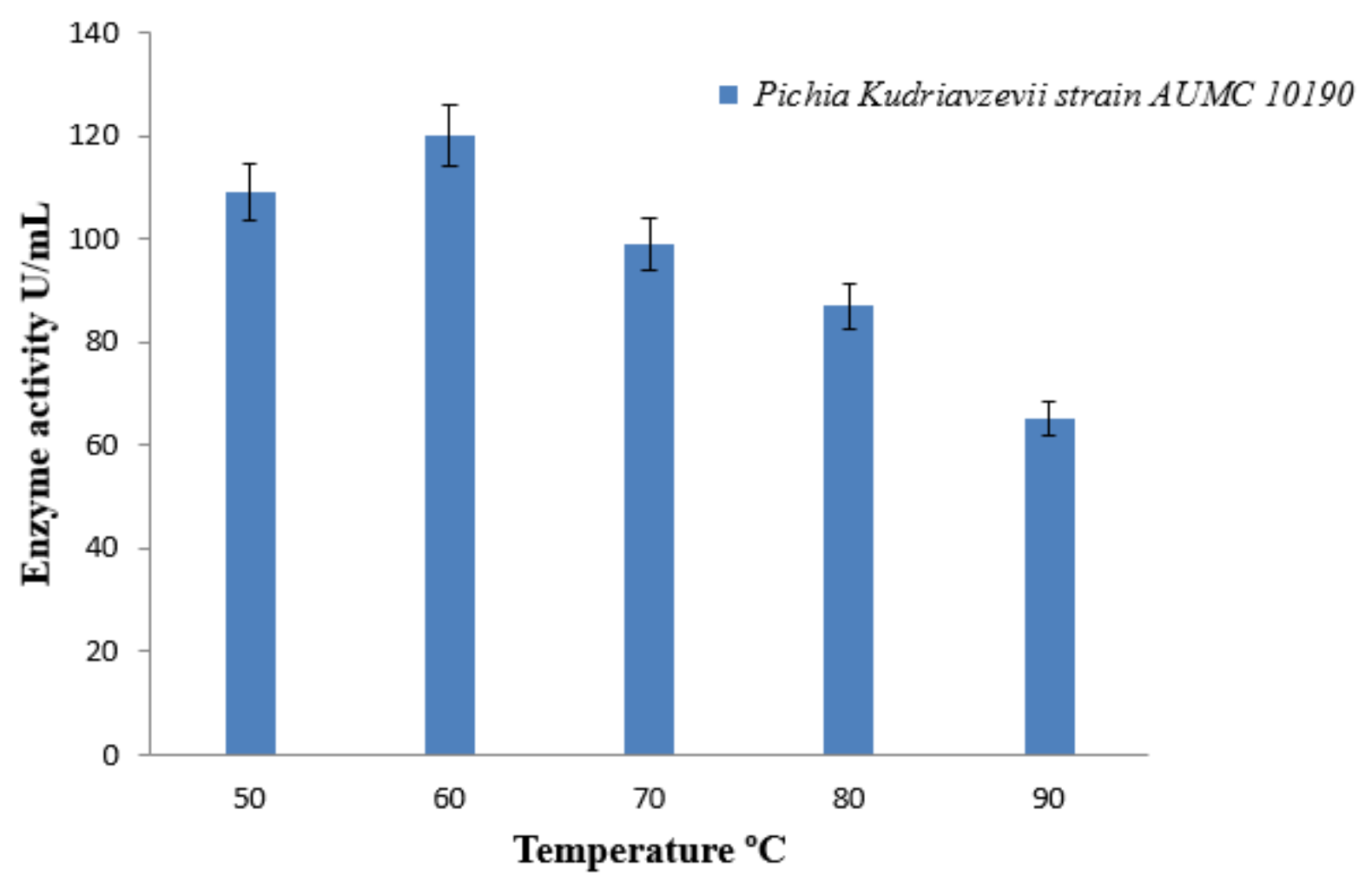

Figure 6

Stability of Mannanase at different temperatures 


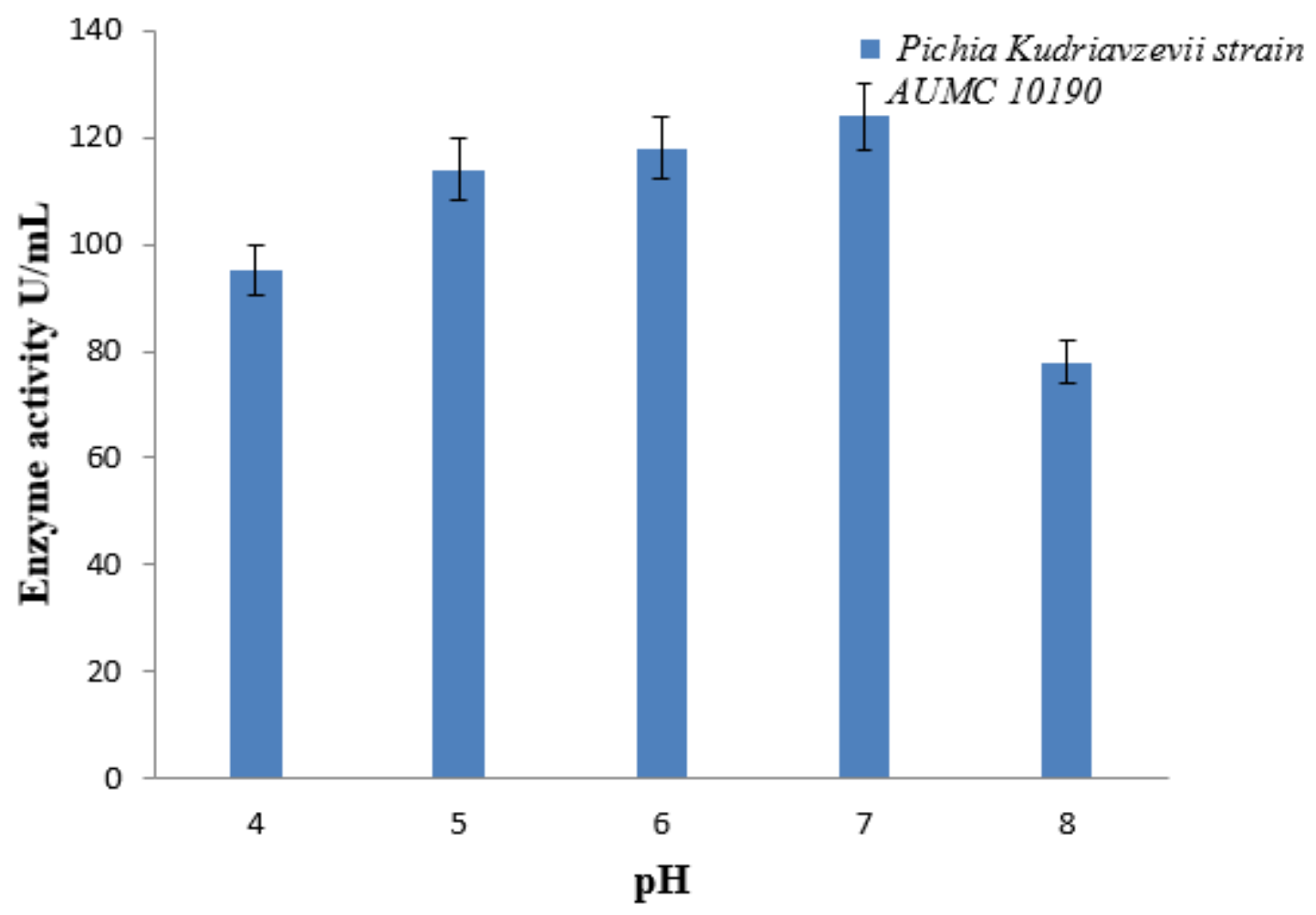

Figure 7

Stability of Mannanase at different $\mathrm{pH}$

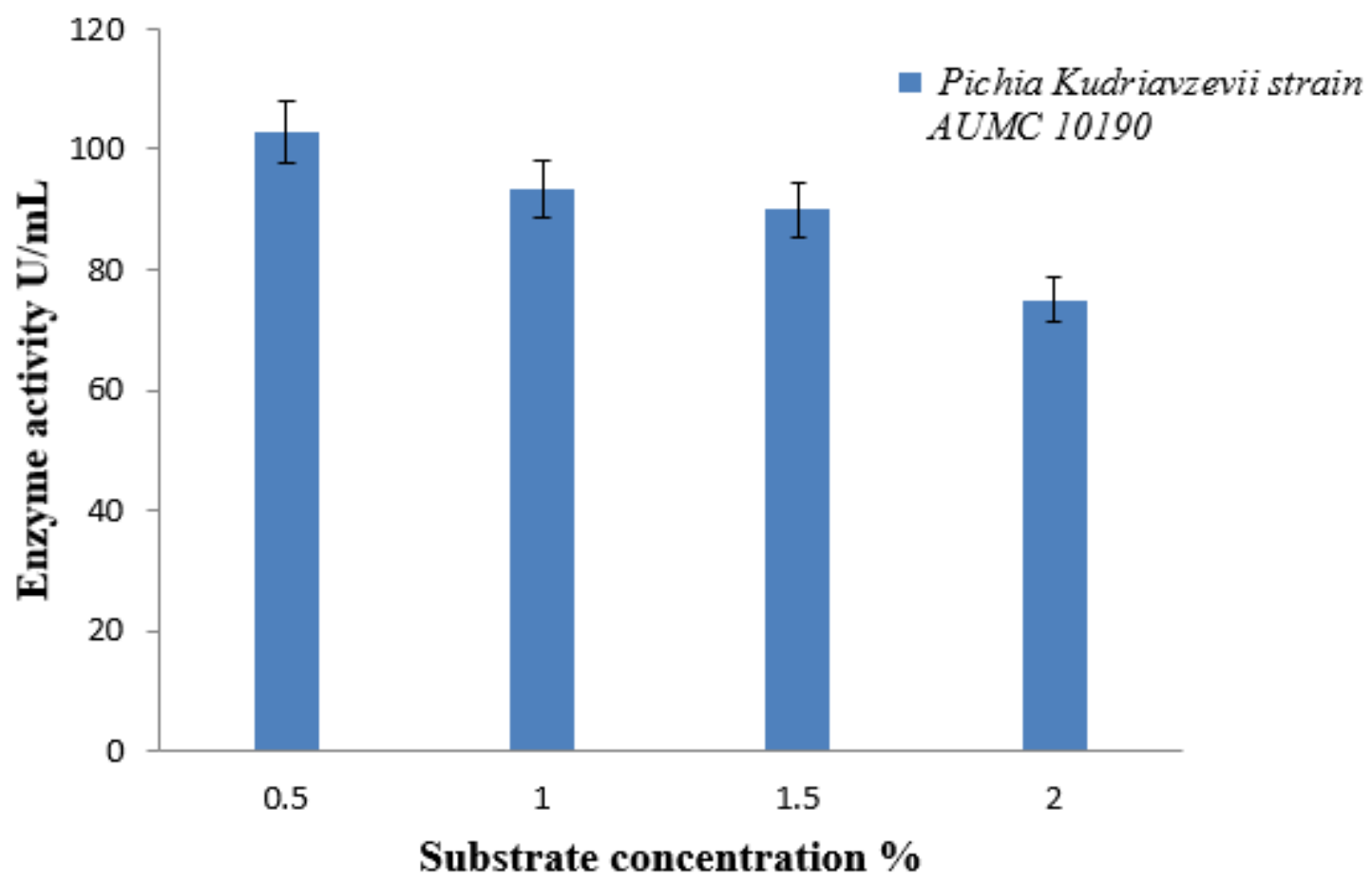


Figure 8

Effect of different Gum arabic concentration on Mannanase stability

\section{Supplementary Files}

This is a list of supplementary files associated with this preprint. Click to download.

- AFOLABINEWGRAPHICALABSTRACT.docx 